addition, grants to N.M., E.H., and R. S. came from N.I.H. Haematology Training Grant No. 5302, Research Grant No. 02776 (Vitamin $\mathrm{B}_{12}$ Metabolism in Tropical Sprue) and No. FR 63-06 from the Division of Research Facilities and Resources, U.S. Public Health Service, Bethesda, Maryland, U.S.A.

\section{REFERENCES}

Bethell, F. H., Meyers, M. C., Andrews, G. A., Swendseid, M. E., Bird, O. D., and Brown, R. A. (1947). fournal of Laboratory and Clinical Medicine, 32, 3.

Butterworth, C. E., jun. (1968). British fournal of Haematology, 14, 339.

Butterworth, C. E., jun., Nadel, H., Perez-Santiago, E., Santini, R., jun. and Gardner, F. H. (1957). Fournal of Laboratory and Clinical Medicine, 50, 673.

Chanarin, I., Anderson, B. B., and Mollin, D. L. (1958). British fournal of Haematology, 4, 156.

Chanarin, I., and McLean, A. (1967). Clinical Science, 32, 57

Dacie, J. V., and Lewis, S. M. (1963). Practical Haematology, 3rd ed. London, Churchill

Herbert, V. (1961). Fournal of Clinical Investigation, 40, 81.

Herbert, V. (1962). Archives of Internal Medicine, 110, 649

Herbert, V., and Zalusky, R. (1962). Fournal of Clinical Investigation, 41, 1263.

Hoffbrand, A. V. (1969). British Medical fournal, 1, 51.

Hoffbrand, A. V., and Necheles, T. F. (1968). Lancet, 2, 528.

Jeejeebhoy, K. N., Desai, H. G., Borkar, A. V., Deshpande, V., and Pathare, S. M. (1968). American fournal of Clinical Nutrition, 21, 994.

Klipstein, $\mathrm{F}$. 42, 638 .

Klipstein, F. A. (1967). American fournal of Clinical Nutrition, 20, 1004.
Klipstein, F. A. (1968). Gastroenterology, 54, 275.

Lear, A. A., Harris, J. W., Castle, W. B., and Fleming, E. M. (1954). fournal of Laboratory and Clinical Medicine, 44, 715.

Lowry, O. H., Rosebrough, N. J., Farr, A. L., and Randall, R. J. (1951). fournal of Biological Chemistry, 193, 265.

Mollin, D. L., Waters, A. H., and Harriss, E. (1962). 2nd European Symposium on Vitamin $B_{12}$ and Intrinsic Factor, edited by H. C. Heinrich, p. 737. Stuttgart, Enke.

O'Brien, W., and England, N. W. J. (1964). British Medical fournal, 2,1573 .

Paterson, D. E., David, R., and Baker, S. J. (1965). British fournal of Radiology, 38, 181.

Perry, J., and Chanarin, I. (1968). British Medical fournal, 4, 546.

Santini, R., jun., Berger, F. M., Berdasco, G., Sheehy, T. W., Aviles, J., and Davila, I. (1962). Fournal of the American Dietetic Association, 41, 562 .

Santini, R., jun., Perez-Santiago, E., Walker, L., and Butterworth, C. E. (1966). American fournal of Clinical Nutrition, 19, 342.

Santini, R., jun., Sheehy, T. W., and Martinez-de Jesus, J. (1961). Gaitroenterology, 40, 772 .

Schertel, M. E., Boehne, J. W., and Libby, D. A. (1965). fournal of Biological Chemistry, 240, 3154.

Sheehy, T. W., Rubini, M. E., Perez-Santiago, E., Santini, R., jun.., and Haddock, J. (1961). Blood, 18, 623.

Spray, G. H. (1952). Clinical Science, 11, 425.

Streiff, R. R., and Rosenberg, I. H. (1967). Fournal of Clinical Investigation, 46, 1121.

Suárez, R. M., Welch, A. D., Heinle, R. W., Suárez, R. M., jun., and Nelson, E. M. (1946). Fournal of Laboratory and Clinical Medicine, 31, 1294 .

Swanson, V. L., and Thomassen, R. W. (1965). American fournal of Pathology, 46, 511 .

Swendseid, M. E., Bird, O. D., Brown, R. A., and Bethell, F. H. (1947). Fournal of Laboratory and Clinical Medicine, 32, 23.

van de Kamer, J. H., ten Bokkel Huinink, H., and Weyers, H. A. (1949). fournal of Biological Chemistry, 177, 347 .

\title{
Acidaemia and Salicylate Poisoning in Adults
}

\author{
A. T. PROUDFOOT,* B.SC., M.R.C.P.ED.; S. S. BROWN, † B.SC., PH.D.
}

British Medical fournal, 1969, 2, 547-550

\begin{abstract}
Summary : A review of the arterial acid-base status on $\checkmark$ admission to hospital of 62 adults with severe salicylate poisoning showed that arterial $p H$ was normal or high in most patients, but low in 8 . The mean plasma salicylate concentrations of the acidaemic and nonacidaemic patients were similar and the difference in arterial $p \mathbf{H}$ was associated with a marked fall in standard bicarbonate in the former group. No significant difference of $\mathrm{PCO}_{2}$ between the two groups was found, and hence no simple relationship exists between hypocapnia and the development of acidaemia in salicylate poisoning. Acidaemia is shown to be associated with impaired consciousness and to carry a grave prognosis.
\end{abstract}

\section{Introduction}

In reviewing acid-base disturbances in salicylate poisoning Smith (1966) stated that there was a "voluminous and often contradictory literature on the subject." Confusion has arisen on three points in particular. (1) Assessment of acid-base status has rarely included measurements of both respiratory and metabolic components; the results of isolated estimates of plasma $\mathrm{CO}_{2}$-combining power are apt to be misconstrued (Greer, Ward, and Corbin, 1965 ; McLaughlin, 1965).

* Senior Medical Registrar, Regional Poisoning Treatment Centre. t Senior Lecturer, University Department of Clinical Chemistry. Royal Infirmary, Edinburgh 3.
Nearly all investigators have used capillary or venous blood samples (Singer, 1954 ; Done, 1960) with attendant difficulties in the collection of specimens or the interpretation of results. (3) Generalizations about the pathogenesis of the disturbance have been made from the findings in acutely poisoned children or in adults treated with therapeutic doses of aspirin (Winters, White, Hughes, and Ordway, 1959) ; the conclusions may not be valid for poisoned adults, in whom there have been few systematic studies (Ghose, 1967 ; Posner and Plum, 1967).

While there is no doubt that acidaemia may be a feature of salicylate poisoning in young children (Tschetter, 1963; Schwartz and Landy, 1965), we are aware of only two specific reports of poisoned adults with arterial $p H$ below normal (Schreiner, Berman, Griffin, and Feys, 1955; Ghose and Joekes, 1964), each concerning only one patient. This suggests that acidaemia is a most uncommon finding in adults. Nevertheless, one patient with capillary $p \mathrm{H}$ below normal was included in the series of Ghose (1967) and a further two patients in that of Morgan and Polak (1969).

In order to determine the incidence of acidaemia, to assess its significance, and to identify the clinical features which might indicate its occurrence, we have reviewed the arterial acid-base findings in 62 severely poisoned adults.

\section{Patients and Methods}

During the three years $1966-8460$ patients over 12 years of age were admitted to the Regional Poisoning Treatment Centre, 
Royal Infirmary, Edinburgh, for the treatment of salicylate poisoning.

Plasma salicylate concentrations on admission and after gastric aspiration and lavage were assayed in the ward sideroom (Brown and Smith, 1968). Arterial blood gas analysis was carried out, before further treatment, in those patients who were found to have salicylate levels exceeding $40 \mathrm{mg} . / 100 \mathrm{ml}$. or who presented with uncommon features of salicylism-for example, impaired consciousness. Thus 62 patients with ages ranging from 14 to 67 years were studied, one patient on two occasions; their age and sex distribution is shown in Fig. 1. Thirty-six of these patients were included in a previous report (Lawson et al., 1969).

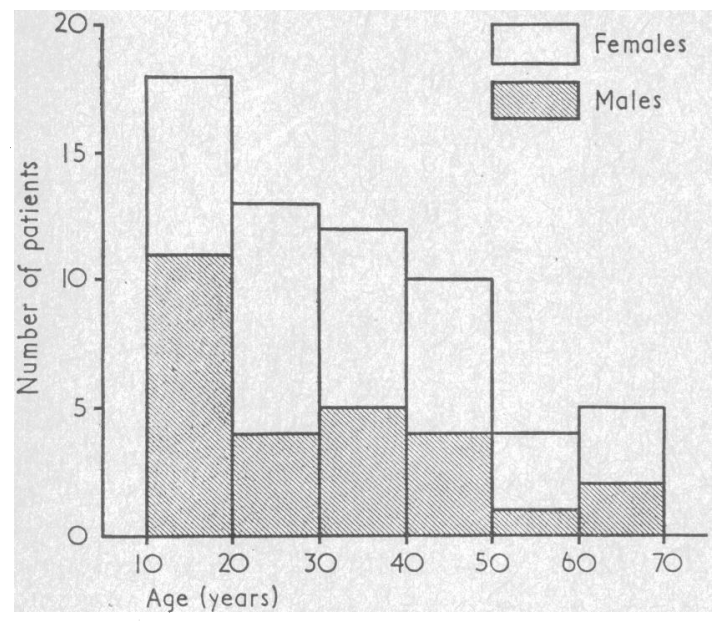

FIG. 1.-Age and sex distribution for 62 patients with severe salicylate poisoning.

Arterial blood samples were obtained by brachial or femoral artery puncture and analysed immediately at $38^{\circ} \mathrm{C}$. by the micro-Astrup equilibration method (Radiometer PHM 27). Temperature correction was not made, as none of the patients was significantly hypothermic or hyperthermic ; oxygen saturation was complete in all cases except when pulmonary oedema developed. Serial venous blood samples were taken for estimation in the laboratory (MacDonald, 1965) of the peak plasma salicylate concentrations. In general patients were treated by forced diuresis (Lawson et al., 1969).

\section{Biochemical Findings}

The initial acid-base status of 62 patients (63 admissions) is summarized in Fig. 2, with an indication of the "normal range" for this hospital (for 100 patients, mean \pm 2 standard deviations of $\mathrm{pH}=7.41 \pm 0.04$; of $\mathrm{PCO}_{2}=39.5 \pm 6.7 \mathrm{~mm}$. Hg ; of standard $\mathrm{HCO}_{3}=24 \cdot 3 \pm 3 \cdot 2 \mathrm{mEq}$. $\left./ 1\right)$. Only one patient had arterial $\mathrm{pH}, \mathrm{PCO}_{2}$, and standard $\mathrm{HCO}_{3}$ within these limits. Most patients showed hypocapnia and metabolic acidosis, and in 22 the $\mathrm{PCO}_{2}$ and standard $\mathrm{HCO}_{3}$ were less than $29.5 \mathrm{~mm}$. $\mathrm{Hg}$ and $19.5 \mathrm{mEq} / 1$. - that is, more than three standard deviations from the normal means.

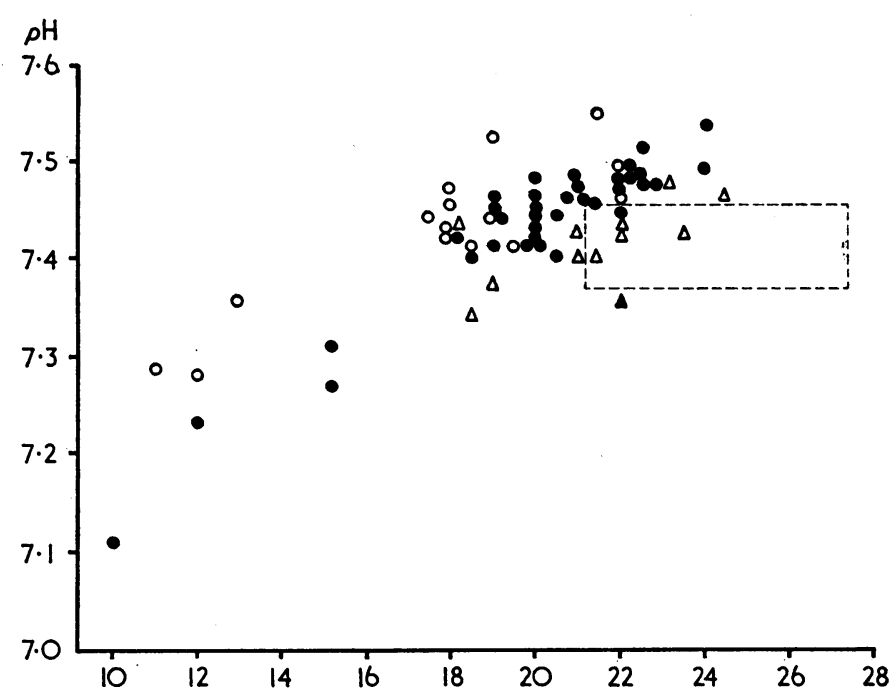

Standard $\mathrm{HCO}_{3}(\mathrm{mEq} / \mathrm{l}$.)

FIG. 2.-Initial arterial acid-base status of 62 severely poisoned patients (63 admissions). The box indicates the normal ranges for $\mathrm{pH}$ and standard $\mathrm{HCO}_{3}$; the symbols indicate the observed $\mathrm{PCO}_{2}(\mathrm{~mm} . \mathrm{Hg})$ :

$$
\text { O } 13-19 ; 020-29 ; \triangle 30-39 ; \Delta 40-47 \text {. }
$$

In 14 males and 16 females the arterial $p \mathrm{H}$ was within the range $7 \cdot 37-7 \cdot 45 ; 12$ males and 12 females showed alkalaemia. Thus 26 males (group A) and 28 females (group B) had normal or high arterial $\mathrm{pH}$ before treatment. Seven females (eight admissions) (group $\mathrm{C}$ ) and one man were acidaemic. The principal biochemical findings in the acidaemic patients are included in Table I.

Except in patients 1, 5, and 6a (Table I), the arterial specimens were taken at or close to the times of peak plasma salicylate concentrations. The relationship of arterial $p \mathrm{H}, \mathrm{PCO}_{2}$ and standard $\mathrm{HCO}_{3}$ to the peak levels, and the relevant linear correlations for the patients of groups A and B, are indicated in Fig. 3.

$$
\begin{array}{c|c|c}
p H \text { v. Salicylate } & \mathrm{PCO}_{2} \text { v. Salicylate } & \text { Standard } \mathrm{HCO}_{3} \text { v. } \\
\mathrm{O}+0.43(<0.05) & -0.56(<0.01) & -0.001(>0.1) \\
\mathrm{O}-0.07(>0.1) & -0.03(>0.1) & -0.32 \quad(=0.1)
\end{array}
$$

\begin{tabular}{|c|c|c|c|c|c|c|c|c|c|c|}
\hline \multirow{2}{*}{$\begin{array}{l}\text { Patient } \\
\text { No. }\end{array}$} & \multirow{2}{*}{ Sex } & \multirow{2}{*}{$\begin{array}{l}\text { Age in } \\
\text { Years }\end{array}$} & \multirow{2}{*}{$\begin{array}{c}\text { Interval } \\
\text { between } \\
\text { Ingestion } \\
\text { and } \\
\text { Admission } \\
\text { (Hours) }\end{array}$} & \multicolumn{3}{|c|}{$\begin{array}{c}\text { Acid-base Status before } \\
\text { Treatment }\end{array}$} & \multirow{2}{*}{$\begin{array}{c}\text { Highest } \\
\text { Measured } \\
\text { Plasma } \\
\text { Salicylate } \\
\text { Concentration } \\
\text { (mg./100 ml.) } \\
\end{array}$} & \multirow{2}{*}{$\begin{array}{c}\text { Level of } \\
\text { Consciousness } \\
\text { on } \\
\text { Admission }\end{array}$} & \multirow{2}{*}{$\begin{array}{l}\text { Response to Forced } \\
\text { Alkaline Diuresis }\end{array}$} & \multirow{2}{*}{ History } \\
\hline & & & & $\begin{array}{c}\text { Arterial } \\
\text { pH }\end{array}$ & $\underset{(\mathrm{mm} . \mathrm{Hg})}{\mathrm{PcO}}$ & $\begin{array}{c}\text { Standard } \\
\mathrm{HCO}{ }_{3} \\
(\mathrm{mEq} / \mathrm{l} .)\end{array}$ & & & & \\
\hline $\begin{array}{l}1 \\
2 \\
3 \\
4\end{array}$ & $\underset{\mathrm{F}}{\mathbf{F}}$ & $\begin{array}{l}16 \\
17 \\
37 \\
38\end{array}$ & $\begin{array}{l}2 \\
4 \\
3 \\
7\end{array}$ & $\begin{array}{l}7.35 \\
7.31 \\
7.36 \\
7.28\end{array}$ & $\begin{array}{l}47 \\
20 \\
13 \\
16.5\end{array}$ & $\begin{array}{l}22 \\
15 \\
13 \\
12\end{array}$ & $\begin{array}{l}65^{*} \\
63 \\
58 \\
40\end{array}$ & $\begin{array}{l}\text { Conscious } \\
\text { Conscious } \\
\text { Conscious } \\
\text { Drowsy }\end{array}$ & $\begin{array}{l}\text { Uneventful } \\
\text { Uneventful } \\
\text { Uneventful } \\
\text { Uneventful }\end{array}$ & $\begin{array}{l}6 \text { months pregnant } \\
\text { Partial gastrectomy; malabsorption; } \\
\text { megaloblastic anaemia; chronie } \\
\text { pyelonephritis }\end{array}$ \\
\hline 5 & $\mathbf{F}$ & 26 & 24 & $7 \cdot 34$ & 30 & 18.5 & 14 & Drowsy & (Not attempted) & $\begin{array}{l}\text { Six months pregnant; chronic } \\
\text { hepatitis }\end{array}$ \\
\hline $6 a$ & $\mathbf{F}$ & 46 & - & $7 \cdot 11$ & 29 & 10 & $50+$ & Unconscious & Pulmonary oedema & $\begin{array}{l}\text { Partial gastrectomy; malabsorption; } \\
\text { osteomalacia; renal tubular } \\
\text { acidosis }\end{array}$ \\
\hline $\begin{array}{l}6 \mathrm{~b} \\
7 \\
8\end{array}$ & $\mathbf{F}$ & $\begin{array}{l}62 \\
47\end{array}$ & $\underset{3}{5}$ & $\begin{array}{l}7.29 \\
7 \cdot 27 \\
7 \cdot 23\end{array}$ & $\begin{array}{l}13.5 \\
27 \\
20.5\end{array}$ & $\begin{array}{l}11 \\
15 \\
12\end{array}$ & $\begin{array}{r}35 \\
75 \\
106\end{array}$ & $\begin{array}{l}\text { Unconscious } \\
\text { Delirious } \\
\text { Delirious }\end{array}$ & $\begin{array}{l}\text { (Not attempted) } \\
\text { Pulmonary oedema } \\
\text { Pulmonary oedema; } \\
\text { died }\end{array}$ & \\
\hline
\end{tabular}

Table II shows the observed ranges of peak salicylate level, and of initial $\mathrm{pH}, \mathrm{PCO}_{2}$, and standard $\mathrm{HCO}_{3}$, with the appropriate means and standard deviations, for the three groups of

Table I.-Principal Biochemical and Clinical Findings in the Acidaemic Patients 
patients. It also summarizes the findings of a statistical comparison of the results for group B with those for groups A and $C$ respectively.
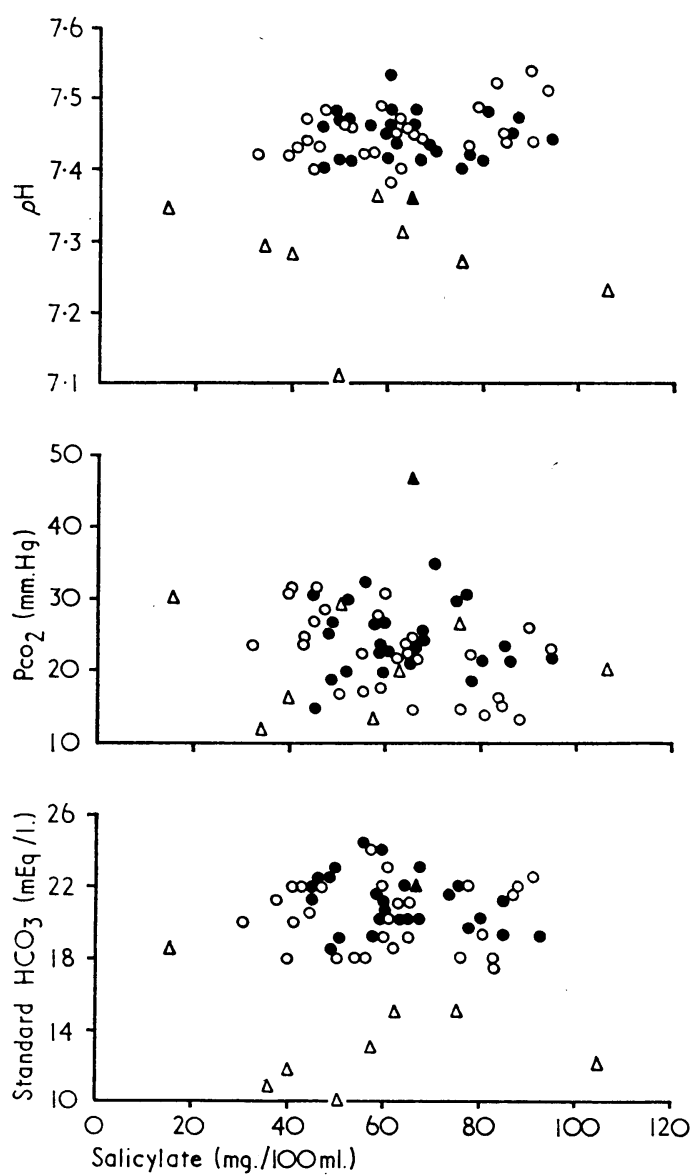

FIG. 3.-Relationship of arterial acid-base measurements to the plasma salicylate concentrations for 62 severely poisoned patients (63 admissions). The open symbols refer to women, and the closed to men; the triangles indicate the acidaemic patients. The linear correlations, $\mathbf{r}(2 \alpha)$, for the non-acidaemic patients are:

\section{Clinical Features in Patients with Acidaemia}

The principal clinical findings in the acidaemic patients are summarized in Table I. In most cases salicylate poisoning was an acute illness, with a lapse of only a few hours between ingestion of overdose and admission to hospital. However, patient 6 became poisoned, before her first admission, as a result of chronic salicylate overdosage. Patient 4 , who was addicted to a compound preparation of aspirin, phenacetin, and codeine, showed marked methaemoglobinaemia, and patient 7 had a blood phenobarbitone level of $3.0 \mathrm{mg} . / 100 \mathrm{ml}$. on admission.
Apart from the latter there was no other evidence of the concomitant ingestion of sedative drugs by the acidaemic patients.

Level of Consciousness.-Patients 1-3 were fully conscious on admission and showed or developed the usual features of salicylism, notably sweating and hyperventilation. Patients 4-8 also showed these signs, but with impairment of consciousness ; patients 4 and 5 were merely very drowsy, while patient 6 on both admissions was unconscious, though responding moderately to painful stimuli. In contrast, patients 7 and 8 showed striking delirium in association with drowsiness.

Forced Diuresis. - Treatment of unconscious patients had to be started before details of the past medical history were known. Forced alkaline diuresis was attempted in seven of the acidaemic patients, with a satisfactory response in terms of changes in acid-base status and plasma salicylate levels. Patients 1-4 tolerated the imposed fluid load without difficulty, but patients 6-8 developed pulmonary oedema, which proved fatal in one case (No. 8).

Médical History.-Three patients (Nos. 3, 5, and 7) were alcoholics, and two (Nos. 3 and 5) were pregnant. Patients 4 and 6 were addicted to salicylate, barbiturates, and other drugs, and had impaired renal function (see below); both of these patients also had malabsorption and other complications of gastric resection. Patient 5 suffered from chronic hepatitis and had been in liver failure on three occasions.

Renal Function.-This was investigated in patients 4-7. In two it was normal, but patient 4 had a creatinine clearance of $36 \mathrm{ml} . / \mathrm{min}$. and radiological changes of pyelonephritis. It was later discovered that patient 6 , who had creatinine clearance of $33 \mathrm{ml} . / \mathrm{min}$., was known to have renal tubular acidosis which had been attributed to analgesic abuse and pyelonephritis. Though details of renal function in patient 8 are not known, necropsy showed no renal abnormality other than glomerular congestion.

\section{Discussion}

To avoid confusion of acid-base terminology we have adopted the definitions set out by Andersen, Astrup, Campbell, Chinard, Nahas, and Winters (1966); in particular, we have restricted the use of the terms "alkalaemia" and "acidaemia" to indicate respectively an arterial blood $\mathrm{pH}$ which is above or below normal.

The present results confirm and extend the findings of previous studies (Ghose, 1967 ; Posner and Plum, 1967) of the acid-base disturbance accompanying severe salicylate intoxication in adults. The majority of patients presenting with plasma salicylate concentrations exceeding $40 \mathrm{mg} . / 100 \mathrm{ml}$. show a mixed disturbance, with metabolic acidosis and respiratory alkalosis, with a resultant arterial $p H$ which is normal or high. Furthermore, a small number of adults show acidaemia; out of 460 admissions on account of salicylate poisoning during the period of this study nine were proved to have an arterial pH below 7.37-an incidence of $2 \%$. It is clearly not valid, therefore, to suggest (Smith, 1966) that poisoned adults usually

Table II.-Comparison of Biochemical Data for the Acidaemic and Non-acidaemic Groups of Patients

\begin{tabular}{|c|c|c|c|c|c|c|c|c|c|c|c|c|c|}
\hline \multirow{3}{*}{ Patients } & \multirow{2}{*}{\multicolumn{3}{|c|}{$\begin{array}{c}\text { Peak Plasma Salicylate } \\
\text { Concentration (mg./100 ml.) }\end{array}$}} & \multicolumn{10}{|c|}{ Arterial Acid-base Status before Treatment } \\
\hline & & & & \multirow{2}{*}{$\begin{array}{l}\mathrm{pH} \\
\text { Range } \\
\end{array}$} & \multicolumn{3}{|c|}{$\left(\mathrm{H}^{+}\right)(\mathrm{m} \mu \mathrm{Eq} / 1)}$. & \multicolumn{3}{|c|}{$\mathrm{PCO}_{2}(\mathrm{~mm} . \mathrm{Hg})$} & \multicolumn{3}{|c|}{ Standard $\mathrm{HCO}_{3}(\mathrm{mEq} / \mathrm{l})}$. \\
\hline & Range | & Mean & S.D. & & Range & Mean & S.D. & Range & Mean & S.D. & Range & Mean & S.D. \\
\hline \multirow{3}{*}{$\begin{array}{l}\text { Group } A \text { (26 admissions; } \\
\text { non-acidaemic men)... } \\
\text { Group B (28 admissions; } \\
\text { non-acidaemic women) } \\
\text { Group C (8 admissions; } \\
\text { acidaemic women) }\end{array}$} & 46-93 & 64 & 13 & $7 \cdot 40-7 \cdot 53$ & $40-30$ & 36 & 0.02 & $15-35 \cdot 5$ & 25 & $4 \cdot 8$ & $18 \cdot 5-24 \cdot 5$ & 21 & 1.6 \\
\hline & $32-92$ & 62 & 17 & $7 \cdot 37-7.54$ & $43-29$ & 36 & 0.03 & $14-32$ & $22 \cdot 5$ & $5 \cdot 5$ & $17 \cdot 5-24$ & 20 & 1.8 \\
\hline & $14-106$ & 55 & 26 & $7 \cdot 11-7 \cdot 36$ & $78-44$ & 54 & $0 \cdot 10$ & $13 \cdot 5-30$ & 21 & $6 \cdot 4$ & $10-18 \cdot 5$ & $13 \cdot 5$ & $2 \cdot 6$ \\
\hline $\begin{array}{l}\text { Student's } t_{\mathrm{B}-\mathrm{A}} \text { (52 degrees } \\
\text { of freedom) }\end{array}$ & \multicolumn{3}{|c|}{$\begin{array}{l}t=-0.58 \\
(2 \mathrm{P}=0.57)\end{array}$} & & \multicolumn{3}{|c|}{$\begin{aligned} t & =-0.29 \\
(2 \mathrm{P} & =0.77)\end{aligned}$} & \multicolumn{3}{|c|}{$\begin{array}{l}t=-1 \cdot 6 \\
(2 P=0.12)\end{array}$} & \multicolumn{3}{|c|}{$\begin{array}{l}t=-1 \cdot 2 \\
(2 P=0 \cdot 26)\end{array}$} \\
\hline $\begin{array}{l}\text { Student's } t_{\mathrm{B}-\mathrm{C}} \text { (34 degrees } \\
\text { of freedom) }\end{array}$ & \multicolumn{3}{|c|}{$\begin{aligned} t & =0 \cdot 81 \\
(2 \mathrm{P} & =0.42)\end{aligned}$} & & \multicolumn{3}{|c|}{$\begin{array}{l}t=-8.3 \\
(2 \mathrm{P}<0.001)\end{array}$} & \multicolumn{3}{|c|}{$\begin{array}{l}t=0.59 \\
(2 \mathrm{P}=0.56)\end{array}$} & \multicolumn{3}{|c|}{$\begin{array}{l}t=8.4 \\
(2 \mathrm{P}<0.001)\end{array}$} \\
\hline
\end{tabular}


exhibit pure respiratory alkalosis and that metabolic acidosis virtually never occurs.

Three patterns of acidaemia, each with particular clinical or biochemical significance, can be distinguished. In only one patient (Table I, No. 1) could acidaemia be attributed to respiratory acidosis. This was a transient state which altered to typical respiratory alkalosis within two hours; the initial acidaemia in this case was of no clinical significance. Carbon dioxide retention in salicylate poisoning has previously been described only in children who developed pulmonary oedema as a terminal event (Winters et al., 1959).

The remaining acidaemic patients were women, several of whom suffered from concurrent disease (Table I). Clinically these patients can be considered in two groups. Patients 2 and 3 showed no unusual clinical signs, and were treated uneventfully by forced alkaline diuresis; again the acidaemia was of no significance. The third group of patients (Nos. 4-8), however, showed impairment of consciousness, and all except No. 5 were gravely ill. Moreover, pulmonary oedema occurred on three out of five occasions on which forced diuresis was attempted; in patient 8 it proved fatal. Impaired consciousness Is a feature we have never seen in patients with normal or high blood $p \mathrm{H}$ except where barbiturate had been taken in addition to salicylate (Lawson et al., 1969). The possibility of concomitant ingestion of drugs other than salicylate in our acidaemic patients must be considered, but we are satisfied that this did not occur except in patients 5 and 7 (see above). It is unlikely that the clinical or biochemical features of salicylism were greatly influenced in either of these cases.

The fact that seven out of the eight acidaemic patients were women suggested that there might be sex-linked differences between the biochemical results for the non-acidaemic patients. Statistical comparison (Table II) of the findings for the male and for the female patients, however, showed no significant differences. It was clear, however, that the occurrence of acidaemia was associated with metabolic acidosis. The findings do not substantiate the view of Tenney and Miller (1955) that acidaemia does not occur in salicylate poisoning except as a reflection of respiratory acidosis after impairment of ventilatory function. At the same time the lack of significant difference between the $\mathrm{PCO}_{2}$ of the acidaemic and the nonacidaemic groups of patients suggests that hypocapnia per se is not the cause of acidaemia, as postulated by Greer et al. (1965) and by Berry and Scheuer (1967). It must be concluded that acidaemia results from interference by salicylate with metabolic pathways (Smith, 1966) leading to the accumulation of organic anions, but the precise mechanism is not understood.

Schwartz and Landy (1965) demonstwated increased urinary excretion of keto-acids and amino-acids in poisoned children, and considered that metabolic acidosis resulted from inadequate renal compensatory mechanisms. While this may be a relevant suggestion in adults with impaired renal function (patients 4 and 6) or subject to chronic intoxication (patient 6a), it is unlikely to be valid when a short time span is involved, as in most of our patients and particularly patient 8 , who became acidaemic within three hours of ingesting an overdose of aspirin. Such individuals must respond abnormally to salicylate in that the rise in circulating organic anions is overwhelming. The fact that adults may so rapidly become acidaemic shows a much closer parallel with poisoning in children (Winters et al., 1959) than has previously been believed, and perhaps indicates one reason why many adults die of salicylate poisoning outside hospital (Campbell, 1963).

It is noteworthy that acidaemia was found in patients with a wide range of peak plasma salicylate concentrations-indeed, the mean value was slightly less than that found for the nonacidaemic patients (Table II). There was also poor correlation of the blood gas measurements with the piasma levels, contrary to the suggestion of Ghose (1967). These points illustrate the difficulty of quantitatively assessing the severity of salicylate poisoning.

In our experience, provided that no sedative drugs have been ingested simultaneously, impairment of consciousness in salicylate poisoning has invariably been associated with acidaemia. In other reports, however, impaired consciousness has been noted in severely poisoned patients with normal or high blood pH (Robin, Davis, and Rees, 1959 ; Posner, Swanson, and Plum, 1965 ; Levy, 1967 ; Morgan and Polak, 1969 ; Savege, Ward, Simpson, and Cohen, 1969). The variation in mental state in these patients is perhaps due to the possibility that the acid-base status of cerebrospinal fluid rather than arterial blood determines the state of consciousness (Posner and Plum, 1967 ; Cameron and Semple, 1968 ; Plum, Posner, and Smith, 1968).

Our experience of the treatment of acidaemic patients is limited, but we feel that the development of acute pulmonary oedema on three of the seven occasions on which forced diuresis was attempted is significant. In these circumstances intravenous fluids should be given at a slower rate than previously advocated (Lawson et al., 1969), at least until acidaemia has been corrected.

We are grateful to Dr. Henry Matthew for his permission and encouragement to report on these patients under his care; to Dr. A. A. H. Lawson and many other colleagues who assisted in the collection of specimens ; and to Miss Jean Cameron, who carried out many of the analyses.

\section{REFERENCES} Andersen, O. S., Astrup, P., Campbell, E. J. M., Chinard, F. P., Nahas,
G. G., and Winters, R. W. (1966). Annals of the New York Academy of Science, 133, 251.

Berry, M. N., and Scheuer, J. (1967). Metabolism, 16, 537.

Brown, S. S., and Smith, A. C. A. (1968). British Medical fournal, 4, 327.

Cameron, I. R., and Semple, S. J. G. (1968). Clinical Science, 35, 391.

Campbell, H. (1963). In Salicylates-An International Symposium, edited by A. St. J. Dixon, B. K. Martin, M. J. H. Smith, and P. H. N. Wood, p. 255. London, Churchill.

Done, A. K. (1960). Pediatrics, 26, 800.

Ghose, R. R. (1967). Postgraduate Medical fournal, 43, 454.

Ghose, R. R., and Joekes, A. M. (1964). Lancet, 1, 1409.

Greer, H. D., Ward, H. P., and Corbin, K. B. (1965). Fournal of the American Medical Association, 193, 555.

Lawson, A. A. H., et al. (1969). Quarterly fournal of Medicine, 38, 31.

Levy, R. I. (1967). Archives of Internal Medicine, 119, 399.

MacDonald, R. P. (1965). Standard Methods of Clinical Chemistry, 5, 237.

McLaughlin, G. E. (1965). Fournal of the American Medical Association, 194, 571 .

Morgan, A. G., and Polak, A. (1969). British Medical fournal, 1, 16.

Plum, F., Posner, J. B., and Smith, W. W. (1968). American fournal of Physiology, 215, 1240.

Posner, J. B., and Plum, F. (1967). New England fournal of Medicine, 277, 605 .

Posner, J. B., Swanson, A. G., and Plum, F. (1965). Archives of Neurology, 12, 479.

Robin, E. D., Davis, R. P., and Rees, S. B. (1959). American fournal of Medicine, 26, 869.

Savege, T. M., Ward, J. D., Simpson, B. R., and Cohen, R. D. (1969). British Medical fournal, 1, 35 .

Schreiner, G. E., Berman, L. B., Griffin, J., and Feys, J. (1955). New England fournal of Medicine, 253, 213.

Schwartz, R., and Landy, G. (1965). Fournal of Pediatrics, 66, 658.

Singer, R. B. (1954). Medicine, 33, 1.

Smith, M. J. H. (1966). In The Salicylates-A Critical Bibliographic Review, edited by M. J. H. Smith and P. K. Smith, p. 257. London, Interscience.

Tenney, S. M., and Miller, R. M. (1955). American fournal of Medicine, $19,498$.

Tschetter, P. N. (1963). American fournal of Diseases of Children, 106, 334.

Winters, R. W., White, J. S., Hughes, M. C., an.I Ordway, N. K. (1959). Pediatrics, 23, 260. 